Original Article

\title{
Spectral analysis, in vitro cytotoxicity and antibacterial studies of bioactive principles from the leaves of Conocarpus lancifolius, a common tree of Jazan, Saudi Arabia
}

\author{
Análise espectral, citotoxicidade in vitro e estudos antibacterianos de princípios bioativos \\ das folhas de Conocarpus lancifolius, uma árvore comum de Jazan, Arábia Saudita
}

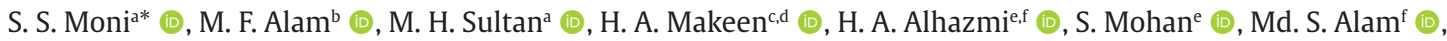

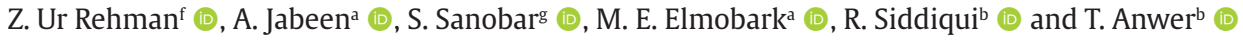 \\ Jazan University, College of Pharmacy, Department of Pharmaceutics, Jazan, Saudi Arabia \\ bJazan University, College of Pharmacy, Department of Pharmacology and Toxicology, Jazan, Saudi Arabia \\ Jazan University, College of Pharmacy, Clinical Pharmacy Department, Pharmacy Practice Research Unit, Jazan, Saudi Arabia \\ Jazan University, Ethnopharmacology Research Unit, Jazan, Saudi Arabia \\ Jazan University, Substance Abuse and Toxicology Research Centre, Jazan, Saudi Arabia \\ fJazan University, College of Pharmacy, Department of Pharmaceutical Chemistry, Jazan, Saudi Arabia \\ gJazan University, College of Pharmacy, Department of Pharmacognosy, Jazan, Saudi Arabia
}

\begin{abstract}
The objective of the present study was to analyse the bioactive compounds of the leaves of Conocarpus lancifolius (C. lancifolius). The GC-MS analysis of the hot methanolic extract of the leaves (HMEL) of C. lancifolius exhibited the bioactive compounds such as 1-(3-Methoxy-2-nitrobenzyl) iso quinoline, morphin-4-ol-6,7-dione, 1-bromo$\mathrm{N}$-methyl-, phytol, hexadecanoic acid, 2,3-dihydroxypropyl ester, 2,2':4',2"-terthiophene, ethyl iso-allocholate, caryophyllene oxide, campesterol, epiglobulol, cholestan-3-ol, 2-methylene-, (3á,5à)-, dasycarpidan-1-methanol, acetate (ester) and oleic acid, eicosyl ester. The FT-IR analysis of HMEL of $C$. lancifolius showed a unique peak at $3184,2413,1657 \mathrm{~cm}^{-1}$ representing coumaric acid, chlorogenic acid and ferulic acid. The HMEL of C. lancifolius was actively inhibiting the proliferation of breast cancer cells MCF-7 ATCC at the concentration of $72.66 \pm 8.21 \mu \mathrm{g} / \mathrm{ml}$ as IC50 value. The HMEL of $C$. lancifolius also revealed a good spectrum of activity against Gram-positive and Gramnegative bacterial cultures screened in this work. The activity observed has shown more or less similar effects against screened bacteria. However, the magnitude of potentiality was significantly lesser compared to standard ciprofloxacin disc at $\mathrm{p}<0.001$ level (99\% confidence intervals). Furthermore, the study demonstrating the bioactive compounds can be isolated from the leaves of $C$. lancifolius.
\end{abstract}

Keywords: plants, leaves, bioactive molecules, multiple drug resistance, anticancer, antibacterial.

\begin{abstract}
Resumo
O objetivo do presente estudo foi analisar os compostos bioativos das folhas de Conocarpus lancifolius (C. lancifolius). A análise por GC-MS do extrato metanólico quente das folhas (HMEL) de C. lancifolius exibiu os compostos bioativos como 1- (3-Metoxi-2-nitrobenzil) isoquinolina, morfina-4-ol-6,7- diona, 1-bromo-N-metil-, fitol, ácido hexadecanoico, 2,3-di-hidroxipropil éster, 2,2 ': 4', 2 " - tertiofeno, isoalocolato de etil, óxido de cariofileno, campesterol, epiglobulol, colestano -3-ol, 2-metileno-, (3á, 5à) -, dasycarpidan-1-metanol, acetato (éster) e ácido oleico, éster eicosílico. A análise FT-IR de HMEL de C. lancifolius mostrou um pico único em 3184, 2413, $1657 \mathrm{~cm}^{-1}$ representando ácido cumarico, ácido clorogênico e ácido ferúlico. O HMEL de C. lancifolius inibiu ativamente a proliferação de células de câncer de mama MCF-7 ATCC na concentração de 72,66 $\pm 8,21 \mu \mathrm{g} / \mathrm{ml}$ como valor de IC50. 0 HMEL de $C$. lancifolius também revelou bom espectro de atividade contra culturas de bactérias Gram-positivas e Gram-negativas rastreadas neste trabalho. A atividade observada mostrou efeitos mais ou menos semelhantes contra bactérias rastreadas. No entanto, a magnitude da potencialidade foi significativamente menor em comparação com o disco de ciprofloxacina padrão em nível de $\mathrm{p}<0,001$ (intervalos de confiança de $99 \%$ ). Além disso, o estudo demonstrando os compostos bioativos pode ser isolado das folhas de $C$. lancifolius.
\end{abstract}

Palavras-chave: plantas, folhas, moléculas bioativas, resistência a múltiplos medicamentos, anticâncer, antibacteriano.

*e-mail: drsmsivakumar@gmail.com; smoni@jazanu.edu.sa

Received: October 10, 2020 - Accepted: January 26, 2021 


\section{Introduction}

Multiple drug resistance (MDR) is one of the foremost therapeutic problems associated with anticancer drug therapy and antibiotics / antibacterial therapy. Therefore, several researchers across the world aimed to develop novel bioactive molecules against cancer and infectious bacterial organisms. Nature is blessed with abundant medicinal plants and trees with unique medicinal values. Traditionally, herbs and medicinal plants were the main resources for curing many diseases across the world in ancient times. Therefore, natural products play a significant role in maintaining a healthy life (Moni et al., 2019). C. lancifolius is a greenish tree that grows around 10 to 30 meters and is widely distributed in Jazan, Saudi Arabia (Figure 1). C. lancifolius, one of the two species in the genus Conocarpus, is a tree that belongs to the family Combretaceae. The tree is fast-growing, heat tolerant, and therefore has been grown in most of the parks and roadsides in Jazan region. It has been reported for medicinal value, especially anti-diabetic and cytotoxicity property (Al-Taweel et al., 2016). Studies suggested that C. lancifolius is used as a food for cattle goats, sheep, and camels in some countries; its wood is used to produce burning fuel, coal and build ships (Wensvoort, 2008). It has been reported as a medicinal plant for the therapy of diabetes mellitus, anaemia, flu, fever, skin ulcers, and syphilis (El-Sayed et al., 2012; Malik et al., 2014). However, there are very limited reports showing the medicinal value of $C$. lancifolius grown in Jazan, Saudi Arabia. This made us to analyse the bio constituents and their medicinal properties to document its therapeutic value.

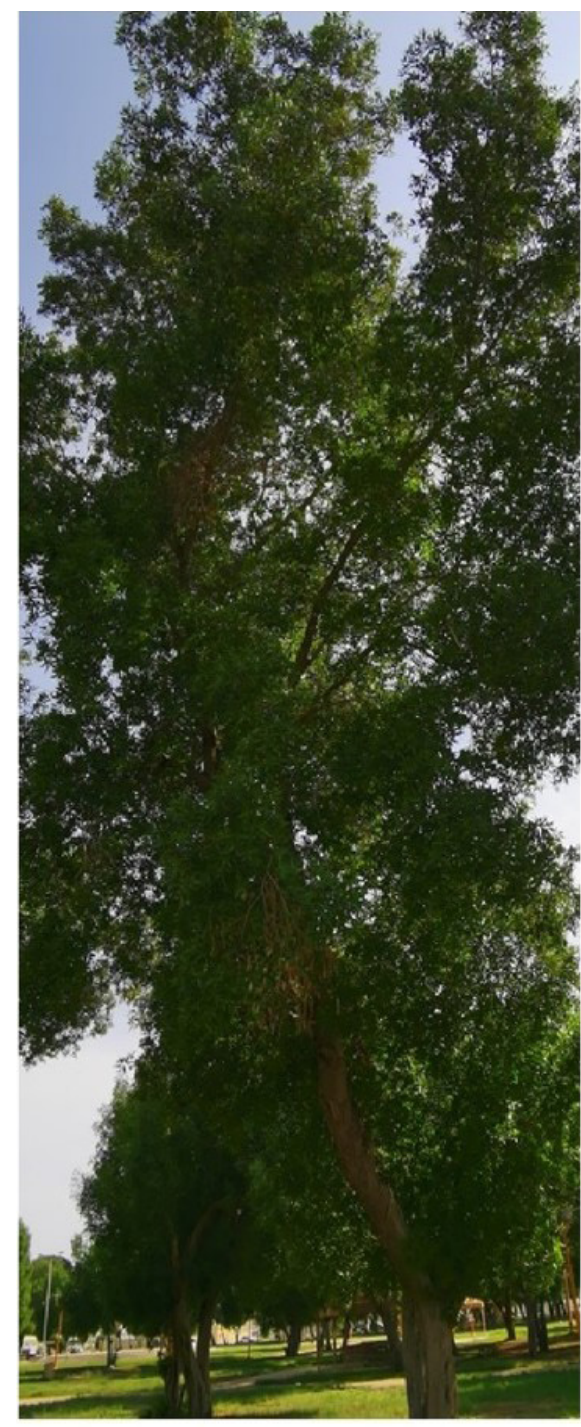

A

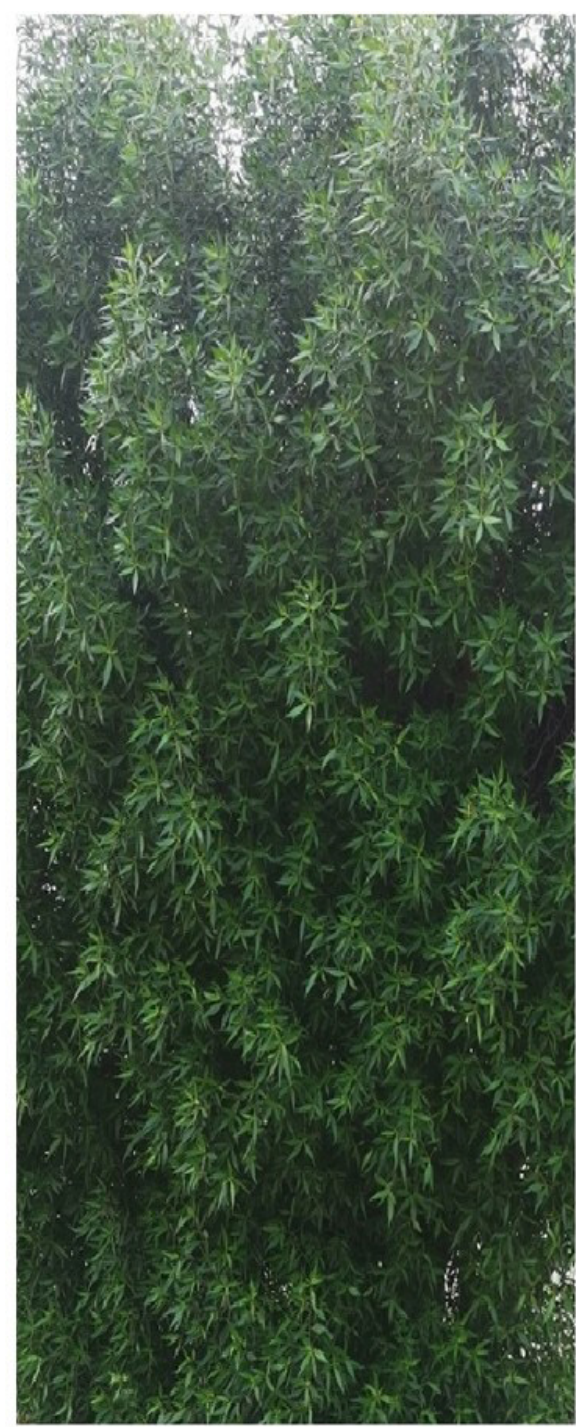

B

Figure 1. The tree Conocarpus lancifolius located in Jazan city, Kingdom of Saudi Arabia (A) Aerial view of the tree shows many bunches of stems with leaves (B) Landscape view of the tree which shows the bunches of the leaves arises from the stem of tree. 


\section{Materials and methods}

\subsection{Collection, identification, and extraction}

Jazan city of Jizan province is located in the southwest part of Saudi Arabia, situated in the Red sea's coastal region. It has a natural habitat of $C$. lancifolius and is planted around the city. The tree branches of $C$. lancifolius was collected by breaking from its main branch and pooled. The collected samples were packed in polythene biohazard yellow bags, tied, and transported to the working laboratory. The leaves of $C$. lancifolius were plucked out from the collected branches and washed thoroughly in normal tap water to remove the impurities. Later the leaves were further washed in Millipore water and air-dried by spreading on the clean floor at room temperature under the shade for 3 weeks. A herbarium curator identified the washed specimens in the Herbarium of Jazan University (JAZUH) and the reference number was 1213 JAZUH. The voucher specimen was also deposited at the herbarium of Jazan University for future reference.

The air-dried leaves were cut into small pieces and powdered using a grinder. The coarsely powdered samples obtained were pooled and kept in an airtight container. Extraction was carried out using a continuous percolation technique with methanol as a solvent. $200 \mathrm{~g}$ of dried leaves powder was subjected to Soxhlet extraction with methanol at $60^{\circ} \mathrm{C}$ for 4 hours. After extraction, the extracts were transferred in a separate glass beaker and kept open for the evaporation of the solvent via an air-drying process. After complete air drying of the leaves extract, dried samples were collected by scraping from the glass beakers and pooled and weighed. The dried powder of the methanolic extract of the leaves (HMEL) of $C$. lancifolius was subjected to various phytochemical analysis, FT-IR and GC-MS studies to determine the various bio compounds present in C. lancifolius.

\subsection{Spectral analysis of the HMEL}

\subsubsection{Gas chromatography-Mass spectrometry (GC-MS) analysis}

A Thermo Scientific GC-MS, AS 3000 autosampler, trace ultra-GC, and ISQ detector were used to identify the structural aspects of the methanolic extract of bioactive compounds. The instrument equipped with a TR 5MS capillary column with dimensions of $30 \mathrm{~m}$ length $\mathrm{x} 0.25 \mathrm{~mm}$ diameter (internal diameter) x $0.25 \mu \mathrm{m}$ (film thickness) was used for the separation of the components. Helium, at a flow rate of $1.2 \mathrm{~mL} / \mathrm{min}$ (constant flow mode), was used as the carrier gas. A volume of $2 \mu \mathrm{L}$ of sample extract was injected in spitless mode. The injection port was set at $320^{\circ} \mathrm{C}$, and the temperature of the oven was initially set at $70{ }^{\circ} \mathrm{C}$ for 5 minutes. The oven temperature was subsequently ramped to $205^{\circ} \mathrm{C}$ at the rate of $5^{\circ} \mathrm{C} / \mathrm{min}$ for 5 minutes; $280^{\circ} \mathrm{C}$ at the rate of $5^{\circ} \mathrm{C} / \mathrm{min}$ for 5 minutes, $290^{\circ} \mathrm{C}$ at the rate of $5^{\circ} \mathrm{C} / \mathrm{min}$ for 5 minutes, and finally to $300^{\circ} \mathrm{C}$ at the rate of $5^{\circ} \mathrm{C} / \mathrm{min}$ for 5 minutes. The maximum oven temperature was set at $320^{\circ} \mathrm{C}$. The mass spectrometer was operated in an electron ionization (EI) mode within the mass range of 60-900 amu with 0.6 scan times ( $\mathrm{min}$ ). The MS transfer line temperature and ion source temperature were kept at $320^{\circ} \mathrm{C}$ and $350^{\circ} \mathrm{C}$, respectively, with an electron multiplier voltage of $1 \mathrm{Kv}$. The mass spectrophotometer was operated and spectral analysis was performed using Xcalibur software. Interpretation of the mass spectrum was determined by using inbuilt software libraries such as NIST, REPLIB, and MAINLIB. The constituent percentages were measured based on the peak area.

\subsubsection{Fourier transform infrared spectroscopy studies (FT-IR)}

The leaf powder was analyzed through FT-IR spectroscopy (Nicolet iS10 FT-IR spectrophotometer) using the pressed pellet technique. The pellet sample's spectra were obtained through the FT-IR spectrophotometer against reference $\mathrm{KBr}$ pellet in the range of $400-4000 \mathrm{~cm}^{-1}$ with a resolution of $4 \mathrm{~cm}^{-1}$.

\subsection{Cytotoxic effect of the HMEL}

In this work, the human breast cancer cell line MCF-7 cell line was cultured and maintained in RPMI-1640 medium at $\mathrm{pH}$ 7.4. Further, $10 \%$ fetal bovine serum (FBS) was added with RPMI-1640 medium as a supplement. Penicillin $(100 \mathrm{U} / \mathrm{ml})$ and streptomycin $(100 \mathrm{~g} / \mathrm{ml})$ were added to the medium. The cells were incubated in a $\mathrm{CO}_{2}$ incubator (Heraeus, $\mathrm{GmbH}$, Germany) at $37^{\circ} \mathrm{C}$ with $90 \%$ humidity and $5 \% \mathrm{CO}_{2}$. The Cells were treated with HMEL of C. lancifolius by dissolving in DMSO while the untreated control cultures received only the vehicle (DMSO < 1\%).

The cytotoxic profile of the HMEL of $C$. lancifolius, was assessed by MTT assay (Syam et al., 2012; Gloria et al., 2019). Briefly, $1 \times 10^{6}$ cells $/ \mathrm{ml}$ was seeded in 96 well microtiter plates for both, and various gradient concentrations of samples were plated out in triplicates and incubated in a $\mathrm{CO}_{2}$ inhibitor for $48 \mathrm{~h}$. Each plate included untreated cell controls and blank cell-free control. After incubation, MTT ( $5 \mathrm{mg} / \mathrm{ml}$ ) was added to each well, and the plates were incubated for a further $4 \mathrm{~h}$ after which the media was removed. DMSO $(100 \mu \mathrm{l})$ was added into each well to solubilize the formazan crystals. The absorbance was read at a wavelength of $570 \mathrm{~nm}$ using a microtiter plate reader (BioTek Instruments, USA). The percentage of cellular viability was calculated with the appropriate controls taken into account. The experiment was done in triplicate, and the following formula was used to calculate the inhibitory rate of cell proliferation: Growth inhibition $=(O D$ control - OD treated) / OD control $\times 100$. The cytotoxicity of the sample on cancer cells was expressed as IC50 values, the sample concentration reducing the absorbance of treated cells by $50 \%$ concerning untreated cells.

\subsection{Morphological changes in treated cells}

Human breast cancer cells MCF-7 was cultured in RPMI- 1640 medium at $\mathrm{pH} 7.4$ by placing in 24 well culture plates and incubated overnight in a $\mathrm{CO}_{2}$ incubator. The cells were then treated in two batches with methanolic extract of C. lancifolius at IC50 and kept for $48 \mathrm{hr}$. After 
the treatment, the first batch treated cells were directly photographed and observed for morphological changes under 20 \& 40X magnifications using Nikon Eclipse TS 100 inverted phase-contrast microscope, Nikon cooperation, Japan. Eclipse TS 100 microscope uses eco illumination that provides sufficient brightness for imaging through phase contrast. The morphological characters were confirmed in the second batch by performing a neutral red dye test. The test was performed by removing the media, and cells were washed with cold, sterile PBS. The washed cells were treated with $0.5 \%$ neutral red at a volume of $100 \mu$ to each well and stained for 2 minutes. The stains were washed out with PBS and immediately observed under phase contrast inverted microscope under 20 \& 40X magnification using Nikon Eclipse TS 100 inverted phase-contrast microscope, Nikon cooperation, Japan.

\subsection{Antibacterial studies}

\subsubsection{Bacterial strains used and standardization}

An equal set of Gram-positive and Gram-negative bacteria was employed in this study, in line with the earlier report (Okhundedaev et al., 2019). Briefly, 24 h cultures of Staphylococcus aureus, Streptococcus pyogenes, Bacillus subtilis, Klebsiella pneumoniae, Escherichia coli and Pseudomonas aeruginosa were prepared in nutrient broth and incubated at $37^{\circ} \mathrm{C}$. The cultures were standardized using serial dilution-agar plate analysis. The cultures were briefly diluted serially using sterilized nutrient broth, resulting in working bacterial culture with a concentration gradient of $10^{-1}$ to $10^{-9}$. Spread plate technique was followed, $100 \mu \mathrm{l}$ of the working bacterial cultures were spread on agar plates with individual organisms in their respective plates. The working bacterial cultures' potential viability was determined in terms of colony-forming unit per ml $(\mathrm{CFU} / \mathrm{ml})$ and tabulated.

\subsubsection{Determination of Minimum inhibitory concentration}

The minimum inhibitory concentration was performed by the broth tube dilution method. The gradient concentrations of samples were prepared by diluting the Millipore water samples to get a predetermined concentration of $1250,1000,750,500,250,125 \mu \mathrm{g} / 100 \mathrm{ml}$. The minimum concentration of inhibiting the bacterial growth was determined based on the visibility of bacterial growth in the broth, and the concentration was noted and used for antibacterial sensitivity studies.

\subsubsection{Antibacterial sensitivity studies}

A specified quantity of Muller Hinton ( $\mathrm{MH}$ ) agar was dissolved in Millipore water and sterilized in an autoclave. The agar plates were prepared aseptically and the spread plate technique was followed to seed the organisms on individual $\mathrm{MH}$ agar plates. The plates were covered with their lids, and the culture was allowed to diffuse through the media for $30 \mathrm{~min}$. Wells of diameter $10 \mathrm{~mm}$ were made using a sterile standard borer for the individual organism, the extracts were placed in the respective wells and plates were incubated at $37^{\circ} \mathrm{C}$ for $24 \mathrm{~h}$. The antibacterial effects of bioactive extracts were quantified by measuring the zone of inhibition around each well in millimetres ( $\mathrm{mm})$.

The Kirby-Bauer technique was employed with standard ciprofloxacin disc ( $5 \mu \mathrm{g} /$ disc). The technique was performed as described earlier in agar well diffusion procedure, but the ciprofloxacin disc was placed on the agar surface rather than in punched well and the plates were incubated at $37^{\circ} \mathrm{C}$ for $24 \mathrm{~h}$. The spectrum of the antibacterial effect of ciprofloxacin disc was determined by measuring the zone of inhibition around the disc and the values were expressed in millimetres ( $\mathrm{mm}$ ).

\section{Results}

The phytochemical analysis of the HMEL of $C$. lancifolius showed various compounds such as carbohydrates, amino acids, alkaloids, tannins, steroids, and saponins. The GC-MS spectral chromatogram (Figure 2) showed possible bioactive compounds in the HMEL of $C$. lancifolius. Figure 3 depicting the structure of bioactive constituents in the HMEL of $C$. lancifolius. The potential bioactive compounds are 1-(3-Methoxy-2-nitrobenzyl) isoquinoline, Morphin-4-ol-6,7-dione, 1-bromo-Nmethyl-, Phytol, Hexadecanoic acid, 2,3-dihydroxypropyl ester, Ethyl iso-allocholate, Caryophyllene oxide, Epiglobulol, Cholestan-3-ol, 2-methylene-, (3á,5à)-, Dasycarpidan-1-methanol, acetate (ester), Campesterol and Oleic acid, eicosyl ester. The FT-IR spectroscopy of the HMEL of $C$. lancifolius was displayed with unique fingerprint regions of various bioactive compounds (Figure 4). The respective compounds of FT-IR analysis were tabulated (Table 1) and represents the presence of possible compounds amino acids, coumaric acid, ferulic acid, Fatty acids, aromatic hydrocarbons, quercetin, tannins, cutins and polysaccharides.

The results of Table 2 suggest that the HMEL of $C$. lancifolius was able to inhibit the proliferation of MCF-7 breast cancer cells. The IC50 value of the HMEL of $C$. lancifolius showed growth inhibition at the concentration of $72.66 \pm 8.21 \mu \mathrm{g} / \mathrm{ml}$ (Figure 5 ). The morphological changes further confirmed the anticancer activity of HMEL of $C$. lancifolius in MCF-7. The non-treated cells had shown typical morphology of healthy MCF-7 cells (Figure 6A \& C). The morphology of control cells was intact, showing clear nucleation and cell differentiation. In contrast, the cells that were treated with extracts had shown detached cells, dead cells, and shrunken cells with condensed or fragmented apoptotic nuclei (Figure 6B \& D). The spectrum of antibacterial effect of HMEL of $C$. lancifolius against selected human pathogenic bacteria including Grampositive Staphylococcus aureus, Streptococcus pyogenes, and Bacillus subtilis; Gram-negative bacteria Escherichia coli, Klebsiella pneumonia, and Pseudomonas aeruginosa was measured. The study revealed that HMEL of $C$. lancifolius exhibited an equal spectrum of activity against Gram-positive and Gram-negative bacteria. The zone of inhibition was expressed in millimetre $(\mathrm{mm})$, which was recorded in Table 3. 


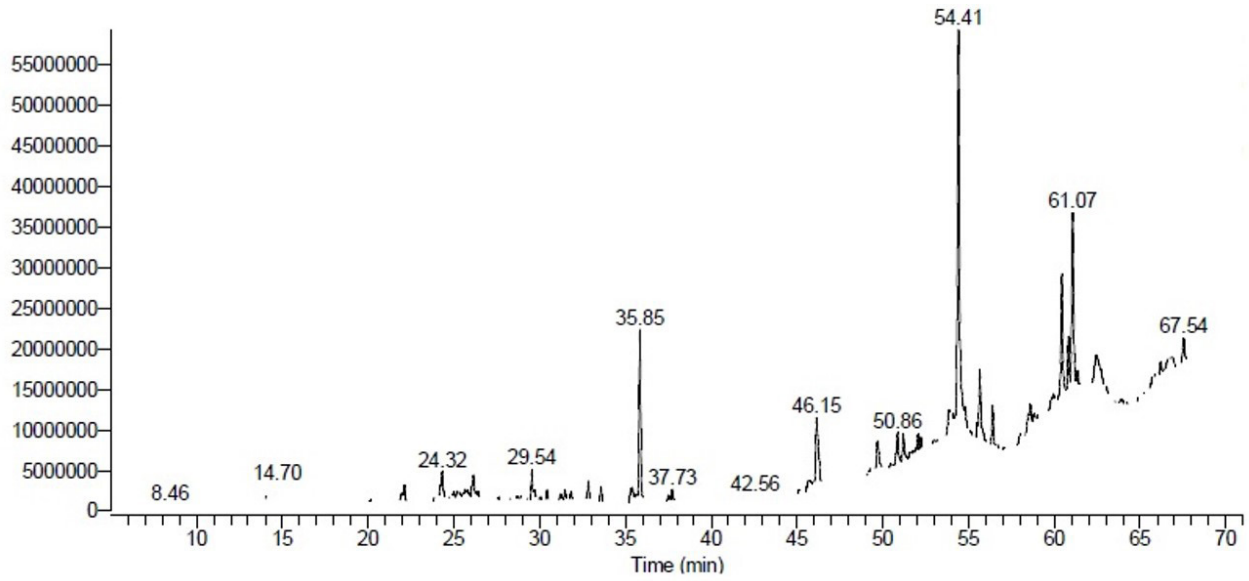

Figure 2. GC-MS spectral chromatogram of the methanolic extract of the leaves (HMEL) of Conocarpus lancifolius.

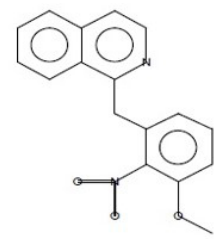

(1)

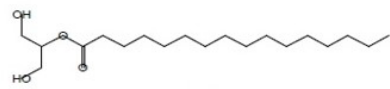

(4)

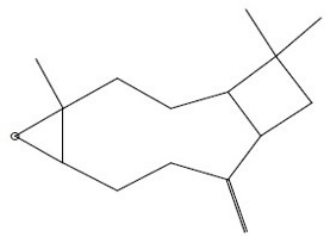

(7)



(10)

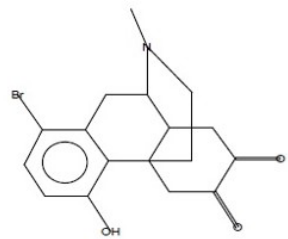

(2)

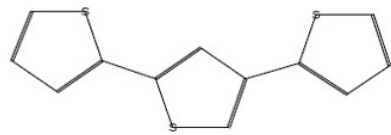

(5)



(8)

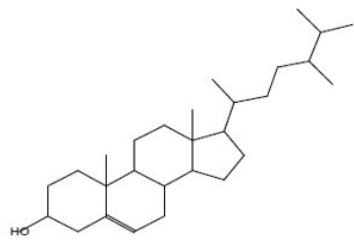

(11)

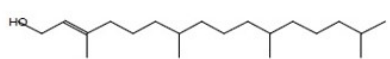

(3)<smiles>CCCC(C)CCC(C)C1CCC2C1C(C)CC1C2C(C)CC2CC(C)CCC21C</smiles>

(6)

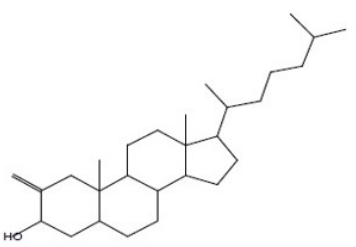

(9)

Figure 3. Bioactive components of the hot methanolic extract of the leaves (HMEL) of Conocarpus lancifolius. (1) 1-(3-Methoxy-2nitrobenzyl) isoquinoline, MF: $\mathrm{C}_{17} \mathrm{H}_{14} \mathrm{~N}_{2} \mathrm{O}_{3}$; MW: 294; RT: 54.41 (2) Morphin-4-ol-6,7-dione, 1-bromo-N-methyl-, $\mathrm{MF} \mathrm{C}_{17} \mathrm{H}_{18} \mathrm{BrNO}_{3}$; MW: 363; RT: 61.07 (3) Phytol, MF: $\mathrm{C}_{20} \mathrm{H}_{40} \mathrm{O}$; MW: 296; RT: 35.85 (4) Hexadecanoic acid, 2,3-dihydroxypropyl ester, $\mathrm{MF} \mathrm{C}_{19} \mathrm{H}_{38} \mathrm{O}_{4}$; MW: 320; RT: 46.15 (5) 2,2':4',2"-Terthiophene, MF: $\mathrm{C}_{12} \mathrm{H}_{8} \mathrm{~S}_{3}$; MW: 248; RT: 50.45 (6) Ethyl iso-allocholate, MF: $\mathrm{C}_{26} \mathrm{H}_{44} \mathrm{O}_{5}$; MW: 436; RT: 56.67 (7) Caryophyllene oxide, MF: $\mathrm{C}_{15} \mathrm{H}_{24} \mathrm{O}$; MW: 220; RT: 24.32 (8) Epiglobulol, MF: $\mathrm{C}_{15} \mathrm{H}_{26} \mathrm{O}$; MW: 222; RT: 25.19 (9) Cholestan-3-ol, 2-methylene-, (3á,5à)-, MF: $\mathrm{C}_{28} \mathrm{H}_{48} \mathrm{O}$; MW: 400; RT: 27.22 (10) Dasycarpidan-1-methanol, acetate (ester), MF: $\mathrm{C}_{20} \mathrm{H}_{26} \mathrm{~N}_{2} \mathrm{O}_{2}$; MW: 326; RT: 32.05 (11) Campesterol, MF: $\mathrm{C}_{28} \mathrm{H}_{48} \mathrm{O}$; MW: 400; RT: 58.60 (12) Oleic acid, eicosyl ester, MF: $\mathrm{C}_{38} \mathrm{H}_{74} \mathrm{O}_{2}$; MW: 562; RT: 58.08. MF Molecular Formula; MW - Molecular Weight; RT - Retention Time (Minutes). 




Figure 4. FT-IR spectroscopy of the hot methanolic extract of the leaves (HMEL) of Conocarpus lancifolius.

Table 1. Phytochemical composition of the hot methanolic extract of the leaves (HMEL) of Conocarpus lancifolius through FT-IR analysis.

Wave number $\left(\mathrm{cm}^{-1}\right)$

\section{Intensity Estimation}

Group or Functional Class

\section{Compounds}

\begin{tabular}{|c|c|c|c|}
\hline \multirow[t]{2}{*}{3184} & W & C-H str. (Aromatic) & Coumaric acid, \\
\hline & & C-H str. (Alkane) & $\begin{array}{l}\text { Aliphatic compounds } \\
\text { Steroids, Tannins, Saponins }\end{array}$ \\
\hline \multirow[t]{2}{*}{2972} & M & C-H str. (Alkene) & Coumaric acid, Aliphatic compounds \\
\hline & & C-H str. (Aldehyde/ketones) & \\
\hline 2541 & $S$ & -SH str. (Thiol) & Amino acids \\
\hline 2413 & M & O-H (Carboxylic acid) & $\begin{array}{l}\text { Coumaric acid, Ferulic acid } \\
\text { Chlorogenic acid }\end{array}$ \\
\hline 2256 & M & CN str. & Fatty acids \\
\hline 2134 & M & $\mathrm{C} \equiv \mathrm{C}$, (Alkyne) & Aromatic hydrocarbons \\
\hline 1925 & $S$ & $\mathrm{CH}$ (Arene) & Aromatic hydrocarbons \\
\hline \multirow[t]{3}{*}{1657} & S & $\mathrm{C}=\mathrm{O} \operatorname{str}$ (Carboxylic group) & \\
\hline & & $\mathrm{C}=\mathrm{C}$ str(Aromatic) & $\begin{array}{l}\text { Quercetin, Coumaric acid, Ferulic acid, } \\
\text { Chlorogenic acid, Ester, Tannins, Pectin }\end{array}$ \\
\hline & & $\mathrm{C}=\mathrm{C}$ str(Alkenes) & \\
\hline 1324 & M & $\mathrm{S}=0$ Stretching (sulfone) & Alkanes \\
\hline 1274 & M & C-O-C Stretching (Ethers) & Quercetin, Tannins \\
\hline 1033 & M & $\mathrm{S}=$ Ostr. & Cutin \\
\hline 880 & $S$ & Out of plane bending & Polysaccharides \\
\hline 803 & M & $\begin{array}{c}=\mathrm{C}-\mathrm{H} \text { bending vibration } \mathrm{NH} \\
\text { (Amines) Out of plane Wagging }\end{array}$ & Quercetin, Fatty acids \\
\hline 664 & M & C-S Stretching & Sulfates \\
\hline
\end{tabular}

W: Weak; M: Medium; S: Strong 
Table 2. Cytotoxic effect of methanolic extract of the leaves (HMEL) of Conocarpus lancifolius against treated MCF-7 cells.

\begin{tabular}{cc}
\hline Drug analyte (Test Sample) & IC50 \\
\hline HMEL $^{*}$ & $72.66 \pm 8.21 \mu \mathrm{g} / \mathrm{ml}$ \\
\hline
\end{tabular}

${ }^{*}$ Hot methanolic extract of the leaves Conocarpus lancifolius MCF-7: Human breast cancer cells. Each value is the mean of $n=3$ batches with standard deviation by performing Dunnett multiple comparison test.

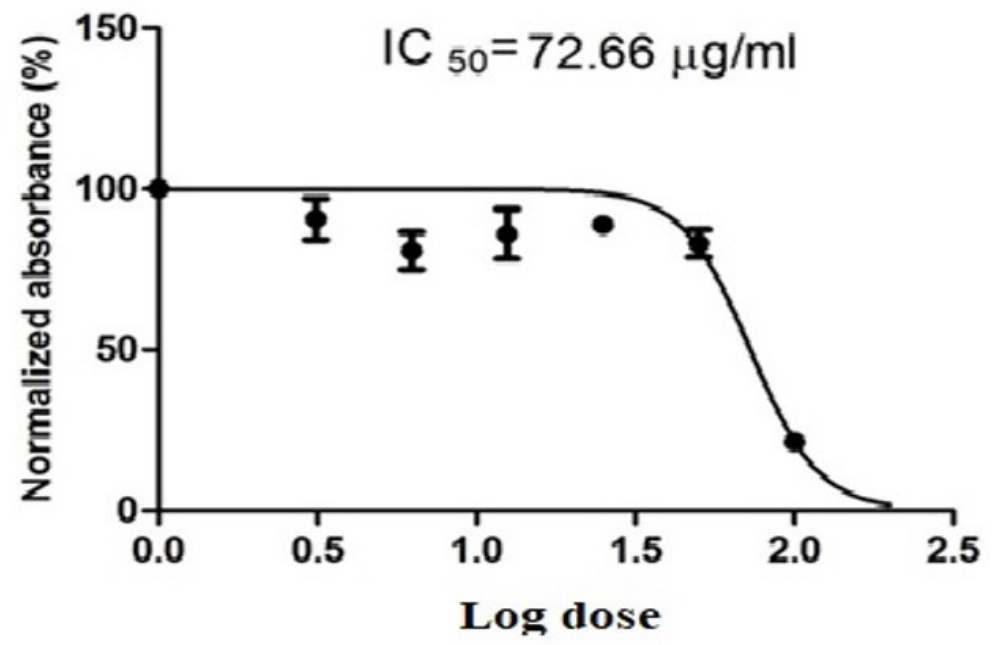

Figure 5. The dose response curve of the hot methanolic extract of the leaves (HMEL) of Conocarpus lancifolius against MCF-7 cells.'

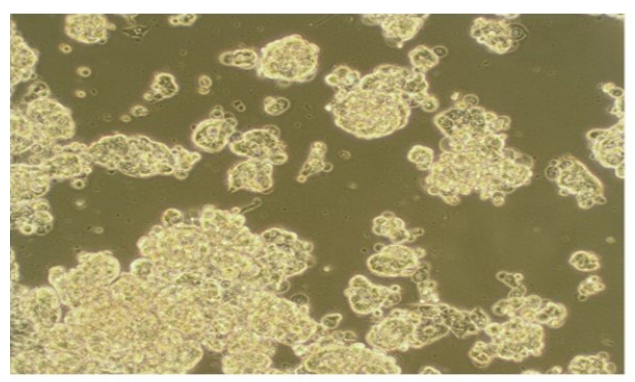

A

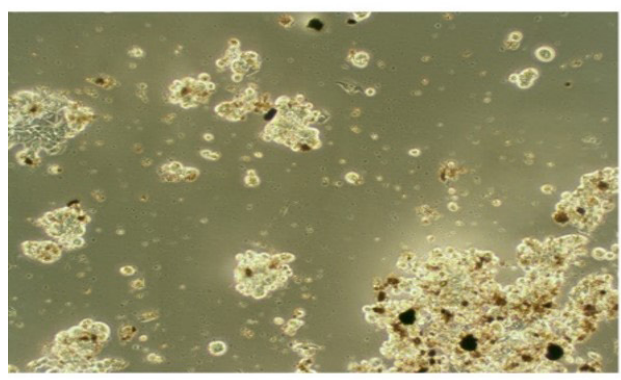

C

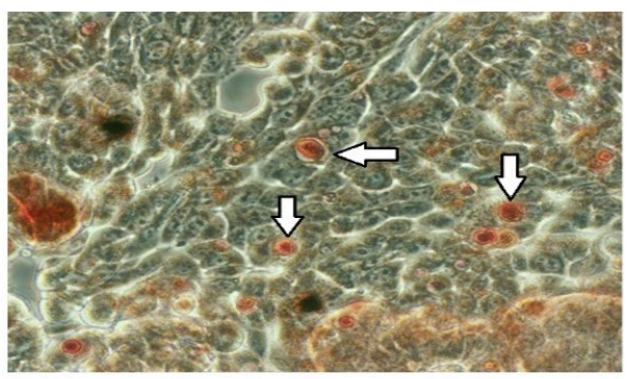

B

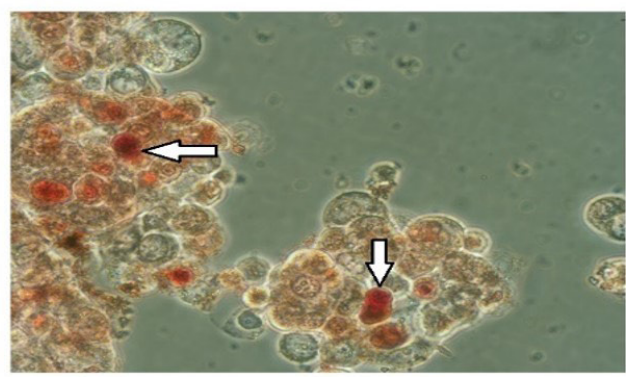

D

Figure 6. Morphology of MCF-7 cells unstained and stained with neutral red after $48 \mathrm{~h}$ treatment with of the hot methanolic extract of the leaves (HMEL) of Conocarpus lancifolius. (A) Microscopical view of unstained healthy cells at $1 \times 10^{6}$ cells / ml concentration mounted at $20 \times$ magnification under phase contrast microscope (B) Microscopical view of stained healthy cells at $1 \times 10^{6}$ cells $/ \mathrm{ml}$ concentration mounted at $20 \times$ magnification under phase contrast microscope (C) Microscopical view of unstained cells after the treatment at $1 \times 10^{6}$ cells $/ \mathrm{ml}$ concentration mounted at $40 \times$ magnification under phase contrast microscope (D) Microscopical view of stained cells after the treatment at $1 \times 10^{6}$ cells / ml concentration mounted at $40 \times$ magnification under phase contrast microscope The arrow arrows of the figure B \& D indicate the nuclei with apoptotic nuclear morphology in both un treated and drug treated cells. 
Table 3. The antibacterial activity of the hot methanolic extract of the leaves (HMEL) of Conocarpus lancifolius against selected human pathogenic bacteria.

\begin{tabular}{|c|c|c|c|c|}
\hline \multirow[b]{2}{*}{ Human pathogenic bacteria } & \multirow[b]{2}{*}{$\begin{array}{l}\text { Concentration } \\
\mathrm{CFU}^{*} / \mathrm{mL}\end{array}$} & \multicolumn{3}{|c|}{ Zone of inhibition (mm) } \\
\hline & & HMEL $^{\text {s }}$ (Test analyte) & $\begin{array}{c}\text { Ciprofloxacin disc } \\
(5 \mu \mathrm{g} / \mathrm{disc})\end{array}$ & $\begin{array}{c}\text { Methanol } \\
\text { (Solvent control) }\end{array}$ \\
\hline Staphylococcus aureus & $2 \times 10^{-5}$ & $18.3 \pm 0.8$ & $27.3 \pm 0.8$ & - \\
\hline Streptococcus pyogenes & $2 \times 10^{-4}$ & $20.3 \pm 1.2$ & $26.6 \pm 0.8$ & - \\
\hline Bacillus subtilis & $3 \times 10^{-6}$ & $18.3 \pm 0.87$ & $28.6 \pm 2.1$ & - \\
\hline Escherichia coli & $4 \times 10^{-6}$ & $21.6 \pm 0.8$ & $31.8 \pm 2.2$ & - \\
\hline Klebsiella pneumonia & $2 \times 10^{-3}$ & $19 \pm 1$ & $28.6 \pm 2$ & - \\
\hline Pseudomonas aeruginosa & $2 \times 10^{-4}$ & $18 \pm 0.9$ & $27 \pm 0.9$ & - \\
\hline
\end{tabular}

(-) No activity; \#CFU - Colony forming unit;

sHMEL - Hot methanolic extract of the leaves; Each value is the mean of $n=6$ batches with standard deviation by performing Dunnett multiple comparison test, (post hoc test). All the test values are significantly lesser than standard ciprofloxacin disc at $P<0.001$ (999\% confidence interval) level.

\section{Discussion}

In the present study, HMEL of $C$. lancifolius exhibited 1-(3-Methoxy-2-nitrobenzyl) isoquinoline, a derivative of the alkaloid isoquinoline. In 2013 researchers reported the antibacterial efficacy of novel isoquinoline derivatives (Galán et al., 2013). Phytol is acyclic diterpene alcohol that has been detected in this study. Phytol is produced by all photosynthetic plants closely associated with chlorophyll (Islam et al., 2018). Phytol is also reported as a major constituent of plant-derived essential oils, and it has potent antimicrobial properties (Murbach Teles Andrade et al., 2014). Hexadecanoic acid, 2,3-dihydroxypropyl ester is a fatty acid derivative that has been detected in HMEL of $C$. lancifolius. Hexadecanoic acid, commonly termed palmitate, has been reported for its antibacterial and antifungal properties (Chandrasekaran et al., 2011; Rahuman et al., 2000). The presence of palmitic acid has been reported in the leaves of $C$. lancifolius in 2011 (Redha et al., 2011). $2,2^{\prime}: 4^{\prime}, 2$ "-terthiophene is an oligomer of the heterocycle thiophene reported for optical properties and anticancer effect (Chiara et al., 2010; Zhang et al., 2009). Ethyl isoallocholate, otherwise called ethyl cholate, was observed in the HMEL of $C$. lancifolius, reported for the antibacterial property (Malathi et al., 2016). However, a recent study has demonstrated reduced tumor growth (Thakur and Ahirwar, 2019). Caryophyllene oxide is a bicyclic sesquiterpene observed in the HMEL of $C$. lancifolius and has been shown as an anticancer molecule (Pan et al., 2016). Epiglobulol is a member of the class of compounds known as 5,10-cycloaromadendrane sesquiterpenoids that have been observed in the HMEL of $C$. lancifolius, which has been reported for antimicrobial activity (Tan et al., 2008). Cholestan-3-ol, 2-methylene-, (3á,5à)-, a saturated tetracyclictriterpene have been determined in the HMEL of $C$. lancifolius. Cholestan-3-ol has already been reported in Canscora perfoliata Lam. (Gentianaceae)
(Thanga Krishna et al., 2012). Dasycarpidan-1-methanol, acetate (ester) an alkaloidal compound has been identified in the HMEL of C. lancifolius in this work which is not yet reported. This compound has been reported for exhibiting anti-inflammatory, antibacterial, antifungal, and anticancer properties (Abeer Fauzi Al et al., 2017). Campesterol and Oleic acid, eicosyl ester were identified in the HMEL of $C$. lancifolius with high retention time. Campesterol is a phytosterol that has not been reported in C. lancifolius. However, the compound has been reported for antioxidant properties (Kmiecik et al., 2011). Oleic acid, eicosyl ester is a monounsaturated omega- 9 fatty acid, that has been reported for having mosquito repellent activity (Gurunathan et al., 2016). The FT-IR spectrum depicted a large parabola-shaped peak observed at $3184 \mathrm{~cm}^{-1}$ with aromatic $\mathrm{C}-\mathrm{H}$ stretching, vibrations, with weak intensity representing the presence of Coumaric acid, aliphatic compounds (Fachriyah et al., 2019). However, alkane stretching indicated the presence of steroids, tannins, saponins. The peak at $2413 \mathrm{~cm}^{-1}$ with medium intensity showed $\mathrm{O}-\mathrm{H}$ (Carboxylic acid), which indicates the presence of Coumaric acid, Chlorogenic acid, and ferulic acid (Gurunathan et al., 2016). The peak at $1657 \mathrm{~cm}^{-1}$ with strong intensity showed $\mathrm{C}=\mathrm{O}$ (Carboxylic group) with stretching vibration, which demonstrated Quercetin, Coumaric acid, and ferulic acid (Gurunathan et al., 2016).

The cytotoxic effect of HMEL of $C$. lancifolius may be due to the presence of hexadecanoic acid, 2,3-dihydroxypropyl. Earlier research findings suggested that the hexadecenoic acid was exhibiting cytotoxicity to human leukemia cells at the concentration of 12.5 to $50 \mu \mathrm{g} / \mathrm{ml}$, but did not show any cytotoxicity to normal human dermal fibroblast (Al-Wahaibi et al., 2020). The anticancer property may also be due to the presence of ethyl isoallocholate, 2,2':4',2"-terthiophene, caryophyllene oxide, and dasycarpidan-1-methanol, acetate (ester). Ethyl isoallocholate has been reported for its potent anticancer 
property and showed the highest cytotoxicity against A549 lung cancer cells in vitro and in vivo (Pan et al., 2016; Fachriyah et al., 2019). Studies have demonstrated the cytotoxic effect of thiophenes. Studies also suggested that caryophyllene oxide has proved to have an anticancer effect against MG-63 human osteosarcoma cells (Pan et al., 2016). The spectrum of antibacterial activity was due to the presence of phytol, hexadecanoic acid, 2,3-dihydroxypropyl ester, and dasycarpidan-1-methanol, acetate (ester). An earlier study suggested that alkaloidal extract from Leaves of $C$. lancifolius exhibited an antibacterial effect (Hayssam et al., 2013). The HMEL of C. lancifolius has exhibited several potentially bioactive compounds that were reflected in the cytotoxicity and antibacterial studies.

\section{Conclusion}

The need to develop novel drug molecules is increasing in demand gradually and steadily because of the development of MDR against cancer and bacterial infections. Plant resources are remarkable sources for the development of medicinal agents from time immortal. The pharmaceutical importance of $C$. lancifolius is not yet explored properly. The present study suggested the presence of certain significant compounds in HMEL of C. lancifolius. The bioactive compounds are hexadecanoic acid, sesquiterpenoids, phytol and dasycarpidan-1methanol, ethyl iso-allocholate, 2,2':4',2"-terthiophene and caryophyllene oxide. The respective compounds were responsible for antimicrobial and cytotoxicity activities. The results obtained in this study are highly promising to develop novel anticancer and antibacterial drug molecules, which will be a significant advancement towards welfare of human society.

\section{Acknowledgements}

The authors are thankful to Dr. Remesh Moochikkal, Department of Biology, Faculty of Science, Jazan University, Saudi Arabia.

\section{References}

ABEER FAUZI AL, R., ASHWAK, F.K. and IMAD, H.H., 2017. Phytochemical screening of methanolic leaves extract of Malva Sylvestris. International Journal of Pharmacognosy and Phytochemical Research, vol. 9, no. 4, pp. 537-552. http://dx.doi. org/10.25258/phyto.v9i2.8127.

AL-TAWEEL, A.M., PERVEEN, S., FAWZY, G.A., MEHMOOD, R., KHAN, A. and KHAN, S.I., 2016. New ellagic acid derivative from the fruits of heat-tolerant plant Conocarpus lancifolius Engl. and their anti-inflammatory, cytotoxic, PPAR agonistic activities. Pakistan Journal of Pharmaceutical Sciences, vol. 29, no. 5, (suppl.), pp. 1833-1837. PMid:28476711.

AL-WAHAIBI, L.H.N., MAHMOOD, A., KHAN, M. and ALKHATHLAN, H.Z., 2020. Comparative study on the essential oils of Artemisia judaica and A. herba-alba from Saudi Arabia. Arabian Journal of Chemistry, vol. 13, no. 1, pp. 2053-2065. http://dx.doi. org/10.1016/j.arabjc.2018.03.004.
CHANDRASEKARAN, M., SENTHIL KUMAR, A. and VENKATESALU, V., 2011. Antibacterial and antifungal efficacy of fatty acid methyl esters from leaves of Sesuvium portulacastrum L. European Review for Medical and Pharmacological Sciences, vol. 15, no. 7, pp. 775-780. PMid:21780546.

CHIARA, B.D., FERRO, R., GIUSEPPE DI, S. and RICCARDO, T., 2010. Structural and optical properties of conjugated molecules in Perhydrotriphenylene (PHTP) and in other channel-forming inclusion compounds. ChemInform, vol. 32, no. 43. http:// dx.doi.org/10.1002/chin.200143264.

EL-SAYED, S.A.H., SALIH, A.B., MOHAMED, M.S., MORTADA, M.E.S. and EMAN, A.E.W., 2012. Phytochemical studies and evaluation of antioxidant, anticancer and antimicrobial properties of Conocarpus erectus L. Growing in Taif, Saudi Arabia. European Journal of Medicinal Plants, vol. 2, no. 2, pp. 93-112. http:// dx.doi.org/10.9734/EJMP/2012/1040.

FACHRIYAH, E., AYU, T. and KUSRINI, D., 2019. Identification of Phenolic acid from ethanol extract leaves binahong (Anredera cordifolia (ten) stennis) and antioxidant activity test. Journal of Physics: Conference Series, vol. 1217, pp. 012051. http://dx.doi. org/10.1088/1742-6596/1217/1/012051.

GALÁN, A., MORENO, L., PÁRRAGA, J., SERRANO, A., SANZ, M.J., CORTES, D. and CABEDO, N., 2013. Novel isoquinoline derivatives as antimicrobial agents. Bioorganic E Medicinal Chemistry, vol. 21, no. 11, pp. 3221-3230. http://dx.doi.org/10.1016/j. bmc.2013.03.042. PMid:23601815.

GLORIA, I., BERTOCCHI, M., ANDREANI, G., FARRUGGIA, G., CAPPADONE, C., SALAROLI, R., FORNI, M. and BERNARDINI, C., 2019. Cytotoxic Effects of Artemisia annua L. and Pure Artemisinin on the D-17 Canine Osteosarcoma Cell Line. Oxidative Medicine and Cellular Longevity, vol. 2019, pp. 1615758. http:// dx.doi.org/10.1155/2019/1615758. PMid:31354901.

GURUNATHAN, A., SENGUTTUVAN, J. and PAULSAMY, S., 2016. Evaluation of mosquito repellent activity of isolated oleic acid, eicosyl ester from Thalictrum javanicum. Indian Journal of Pharmaceutical Sciences, vol. 78, no. 1, pp. 103-110. http:// dx.doi.org/10.4103/0250-474X.180259. PMid:27168688.

HAYSSAM, M.A., MOHAMED, Z.M.S. and AHMED, A.M., 2013. Invitro antibacterial activities of alkaloids extract from leaves of Conocarpus lancifolius Engl. Journal of Pure E Applied Microbiology, vol. 7, no. 3, pp. 1903-1907.

ISLAM, M.T., ALI, E.S., UDDIN, S.J., SHAW, S., ISLAM, M.A., AHMED, M.I., CHANDRA SHILL, M., KARMAKAR, U.K., YARLA, N.S., KHAN, I.N., BILLAH, M.M., PIECZYNSKA, M.D., ZENGIN, G., MALAINER, C., NICOLETTI, F., GULEI, D., BERINDAN-NEAGOE, I., APOSTOLOV, A., BANACH, M., YEUNG, A.W.K., EL-DEMERDASH, A., XIAO, J., DEY, P., YELE, S., JÓŹWIK, A., STRZAŁKOWSKA, N., MARCHEWKA, J., RENGASAMY, K.R.R., HORBA CZUK, J., KAMAL, M.A., MUBARAK, M.S., MISHRA, S.K., SHILPI, J.A. and ATANASOV, A.G., 2018. Phytol: a review of biomedical activities. Food and Chemical Toxicology, vol. 121, pp. 82-94. http://dx.doi. org/10.1016/j.fct.2018.08.032. PMid:30130593.

KMIECIK, D., KORCZAK, J., RUDZIŃSKA, M., KOBUS-CISOWSKA, J., GRAMZA-MICHAŁOWSKA, A. and HĘŚ, M., 2011. $\beta$-Sitosterol and campesterol stabilisation by natural and synthetic antioxidants during heating. Food Chemistry, vol. 128, no. 4, pp. 937-942. http://dx.doi.org/10.1016/j.foodchem.2011.03.122.

MALATHI, K., ANBARASU, A. and RAMAIAH, S., 2016. Ethyl Isoallocholate from a medicinal rice Karungkavuni inhibits dihydropteroate synthase in Escherichia coli: a molecular docking and dynamics study. Indian Journal of Pharmaceutical Sciences, vol. 78, no. 6, pp. 780-788. http://dx.doi.org/10.4172/ pharmaceutical-sciences.1000184. 
MALIK, S., BASHIR, A.C., MUHAMMAD, U. and KHURRAM, A., 2014. Antidiabetic potential of Conocarpus lancifolius. Bangladesh Journal of Pharmacology, vol. 9, pp. 244-249. http://dx.doi. org/10.3329/bjp.v9i2.18556.

MONI, S.S., HADI SULTAN, M., MAKEEN, H.A., JABEEN, A., SANOBAR, S., SIDDIQUI, R., UR REHMAN, Z., ALAM, M.S., AHMAD, S. ELMOBARK, M.E. and MOOCHIKKAL, R., 2019. Phytochemical and spectral analysis of the methanolic extracts of leaves of Murraya koenigii of Jazan, Saudi Arabia. Natural Product Research, pp. 1-5. http://dx.doi.org/10.1080/14786419.2019.1 679137. PMid:31631708.

MURBACH TELES ANDRADE, B.F., NUNES BARBOSA, L., DA SILVA PROBST, I. and FERNANDES JÚNIOR, A., 2014. Antimicrobial activity of essential oils. The Journal of Essential Oil Research, vol. 26, no. 1, pp. 34-40. http://dx.doi.org/10.1080/10412905 .2013.860409.

OKHUNDEDAEV, B.S., BACHER, M., MUKHAMATKHANOVA, R.F., SHAMYANOV, I.J., ZENGIN, G., BÖHMDORFER, S., MAMADALIEVA, N.Z. and ROSENAU, T., 2019. Flavone glucosides from Artemisia juncea. Natural Product Research, vol. 33, no. 15, pp. 21692175. http://dx.doi.org/10.1080/14786419.2018.1490901. PMid:30422004

PAN, Z., WANG, S.K., CHENG, X.L., TIAN, X.W. and WANG, J., 2016. Caryophyllene oxide exhibits anticancer effects in MG-63 human osteosarcoma cells via the inhibition of cell migration, generation of reactive oxygen species and induction of apoptosis. Bangladesh Journal of Pharmacology, vol. 11, no. 4, pp. 817-823. http://dx.doi.org/10.3329/bjp.v11i4.27517.

RAHUMAN, A.A., GOPALAKRISHNAN, G., GHOUSE, B.S., ARUMUGAM, S. and HIMALAYAN, B., 2000. Effect of Feronia limonia on mosquito larvae. Fitoterapia, vol. 71, no. 5, pp. 553-555. http:// dx.doi.org/10.1016/S0367-326X(00)00164-7. PMid:11449505.

REDHA, A., AL-MANSOUR, N., SULEMAN, P., AFZAL, M. and ALHASAN, R., 2011. Leaf Traits and histochemistry of trichomes of Conocarpus lancifolius a Combretaceae in semi-arid conditions.
American Journal of Plant Sciences, vol. 2, no. 2, pp. 165-174. http://dx.doi.org/10.4236/ajps.2011.22018.

SYAM, S., ABDELWAHAB, S., AL-MAMARY, M.A. and MOHAN, S., 2012. Synthesis of chalcones with anticancer activities. Molecules (Basel, Switzerland), vol. 17, no. 6, pp. 6179-6195. http://dx.doi. org/10.3390/molecules17066179. PMid:22634834.

TAN, M., ZHOU, L., HUANG, Y., WANG, Y., HAO, X. and WANG, J., 2008. Antimicrobial activity of globulol isolated from the fruits of Eucalyptus globulus Labill. Natural Product Research, vol. 22, no. 7, pp. 569-575. http://dx.doi.org/10.1080/14786410701592745. PMid: 18569693.

THAKUR, R.S. and AHIRWAR, B., 2019. A steroidal derivative from Trigonella foenum graecum $\mathrm{L}$. that induces apoptosis in vitro and in vivo. Journal of Food and Drug Analysis, vol. 27, no. 1, pp. 231-239. http://dx.doi.org/10.1016/j.jfda.2018.05.001. PMid:30648576.

THANGA KRISHNA, K.S., MUTHUKUMARASAMY, S. and MOHAN, V.R., 2012. GC-MS determination of bioactive components of Canscora perfoliata Lam. (Gentianaceae). Journal of Applied Pharmaceutical Science, vol. 2, no. 8, pp. 210-214.

WENSVOORT, J., 2008. Browse silage in the United Arab Emirates. Wildlife Middle East News, vol. 3, no. 1, pp. 1-2.

ZHANG, P., LIANG, D., JIN, W., QU, H., CHENG, Y., LI, X. and MA, Z., 2009. Cytotoxic thiophenes from the root of Echinops grijisii Hance. Zeitschrift fur Naturforschung. C, Journal of biosciences, vol. 64, no. 3-4, pp. 193-196. http://dx.doi.org/10.1515/znc2009-3-407. PMid:19526711.

\section{Abbreviations}

HMEL, hot methanolic extract of the leaves; GC-MS, Gas chromatography-mass spectrometry; FT-IR, Fourier transform - infrared spectroscopy; MDR, Multiple drug resistance; MTT, 3-[4,5-dimethylthiazole-2-yl]-2,5diphenyltetrazolium bromide; IC, Inhibitory concentration 